Article

\title{
Revitalizing Traditional Agricultural Practices: Conscious Efforts to Create a More Satisfying Culture
}

\author{
Johanna Dahlin*(D) and Elin Svensson \\ Department of Culture and Society, Linköping University, SE-601 74 Norrkoping, Sweden; \\ elinmesvensson@gmail.com \\ * Correspondence: johanna.dahlin@liu.se
}

Citation: Dahlin, J.; Svensson, E. Revitalizing Traditional Agricultural Practices: Conscious Efforts to Create a More Satisfying Culture. Sustainability 2021, 13, 11424. https:// doi.org/10.3390/su132011424

Academic Editor: Andrea Pezzuolo

Received: 16 August 2021

Accepted: 11 October 2021

Published: 15 October 2021

Publisher's Note: MDPI stays neutral with regard to jurisdictional claims in published maps and institutional affiliations.

Copyright: (c) 2021 by the authors. Licensee MDPI, Basel, Switzerland. This article is an open access article distributed under the terms and conditions of the Creative Commons Attribution (CC BY) license (https:/ / creativecommons.org/licenses/by/ $4.0 /)$.

\begin{abstract}
This paper investigates how non-industrial agrarian traditions and practices are reworked and recontextualized in a contemporary context. Explorative in its nature, the paper uses in depth interviews with practitioners in eastern Sweden, several of whom are engaged in work to keep practices of the past alive, to discuss how the concept of revitalization can bear on sustainability. Traditional practices are revived as an alternative to industrialized agriculture, and as having a bearing on resilient cultivation systems as well as social relations. They are seen as means of increasing food security and reversing the negative biodiversity development caused by increased monoculture. We understand tradition as a process of negotiation and adaptation to the present, where revivals to some extent necessarily change the traditions that they attempt to revive. Tradition is thus a dynamic concept, always made in the present, never fixed but constantly evolving. In the challenges created by climate change and environmental degradation, it is increasingly voiced that true sustainability requires a transformation of the cultural system. In many cases, people are turning to tradition for sustainable alternatives to industrialized ways of life and to protect a diversity threatened by a dominant and unsustainable lifestyle.
\end{abstract}

Keywords: revitalization; tradition; sustainability; traditional agriculture; Sweden

\section{Introduction}

At a small, enclosed courtyard at our university campus, some members of the biology department have created a meadow. Surrounded by a 1970s building, this is not the typical setting for this kind of field, but it is scythe mowed and worked in a traditional way. In an interview with the university news, one of the initiators explains how the specific technique of scything is to be done, indicating that it takes a lot of work to learn [1]. Once a widespread feature of the rural landscape in Sweden, these kinds of meadows have become increasingly rare with the change towards large-scale industrialized farming and machine mowing.

The interview is focused on how scythe mowed meadows can contribute to biodiversity due to the specific way in which the scythe cuts the grass, and how the removal of the grass results in a meagre soil in which a rich variety of plants can thrive and attract pollinating insects. The environmental impact of lawns has been subject to both research [2] and public discussion in recent years, and in a related university news item it is mentioned that the city of Linköping, where the campus is located, has created 17 meadows as more sustainable alternatives to lawns [3].

The campus meadow can thus be seen as part of a recent trend highlighting the environmental benefits of creating "pockets" of more biologically diverse and less fossil fuel intensive greenery in urban areas, a setting that might be considered untraditional given the association of scythe mowing and meadows with agrarian history. Scythe mowing is one example of a practice that once was a natural element in people's everyday lives. Things that once were a matter of course, things "one just did", have today become 
recontextualized as conscious acts. In many cases, people are turning to tradition for sustainable alternatives to industrialized ways of life and to protect a diversity threatened by modernity in the form of a dominant and unsustainable lifestyle. The inspiration for such revitalization is found in traditional and non-industrial ways of living. Examples may include medicinal plants, landrace breeds, seed circles, craft techniques, patterns and materials. In this paper, we are interested in this conscious relation to past practices, connected with traditional agriculture, and how tradition is envisioned as a model for the future.

This paper explores how the concept of revitalization can bear on and deepen our understanding of sustainability. We are working with an understanding of sustainability as a human centred concept that concerns the human impact on, and relationship with, the environment. Sustainability is thus not only to be understood in ecological terms, but is a concept with at least seven key dimensions: ecological, political, ethical, socio-economic, democratic, cultural and spiritual [4]. To a large extent, our discussion is focused on sustainability's cultural dimensions, although these, of course, cannot be disconnected from the other dimensions. We agree with Vogt and Weber that sustainability "means a new ethical-cultural orientation" ([4], p. 6), and revitalization is a concept that helps us to direct our attention to these aspects of sustainability, as well as its temporal dimensions.

Traditional practices are revived as an alternative to industrialized agriculture, and are seen as having a bearing on resilient cultivation systems. Proponents suggest that traditional practices can improve food security and reverse the negative biodiversity development caused by increased monoculture. The revitalization of traditional practices is also presented as having a bearing on social relations, where the more satisfying culture is thought of in terms of community.

While the revitalisation practices that we study have the potential to contribute to environmental sustainability, our purpose is not to make any claims to the actual environmental impact or benefit of these practices. Instead, we are primarily interested in how revitalization aims to sustain and reinvoke culturally significant practices. In particular, this paper investigates interest in and attempts to revive and revitalize traditional agricultural practices in Sweden. It is explorative in its nature, and empirically based on in-depth interviews with practitioners in south-eastern Sweden, several of whom are engaged in work to maintain practices of the past, such as seed saving, beekeeping, or scything. The paper also has a theoretical focus, engaging with the concept of revitalization.

The concept of revitalization originates in sociocultural anthropology, and our point of departure is Anthony Wallace's understanding of a revitalization movement as a "deliberate, organized, conscious effort by members of a society to construct a more satisfying culture" ([5], p. 256). Wallace's general definition of revitalization movements and many of his insights into these movements provide a workable foundation for further theoretical work. In using the term revitalization, we assume that there are cultural or identity dimensions to these practices. In the challenges created by climate change and environmental degradation, it is increasingly voiced that true sustainability requires such a cultural transformation that Wallace's definition hints at [6]. In many cases, people are turning to tradition for sustainable alternatives to industrialized ways of life and to protect a diversity threatened by a dominant and unsustainable lifestyle. Revitalization is thus a signal of stress and distortion, as it can be seen as a crisis response.

Revitalization can be seen as a reaction to industrial modernity and the homogenizing forces of majority cultures, although the reactions operate at different levels and with different goals: revitalization can operate locally and aims to preserve and protect specific customs and resources, but it also operates at a structural level, aiming to promote systemic change. As this text will show, those two levels are related.

\section{Investigating Traditional Agrarian Practices}

The study used the conceptual framework as its point of departure, and it was designed as a mapping or survey of practices which may fit the bill as revitalization, broadly 
conceived, in a contemporary agrarian context. In this way, it was intended as an exploration of the usefulness of the concept of revitalization for understanding the relationship between tradition and sustainability. During the course of the work, there has been an abductive movement between theory and empirical findings which in turn has influenced and helped develop the theoretical framework. The traditions and practices that are investigated in this paper are non-industrial, small-scale and connected to everyday life.

The study is based on interviews with people who, in different ways, engage in traditional methods and practices to cultivate land and provide for people. This includes interviewees that are engaged in seed keeping, small-scale agriculture and cultivation, urban agriculture, local history societies, and food crafts-but also those who are holders of traditional knowledge that has been silently passed between generations. This means that some of our interviewees have been interviewed as individual practitioners, while others have been interviewed as representatives of associations or organizations. The interviewees also represent a wide range of ages. With few exceptions, the interviewees are based in a region in south-eastern Sweden which long has been one of the country's most significant agricultural areas.

The interviews followed a semi structured interview guide with focus on motivation behind involvement in traditional practices, and knowledge transfer. Hence, the interviews provide insight in the motives and beliefs among practitioners, but they also highlight efforts to pass on such knowledge to others in order to keep it alive in a context where people seldom naturally encounter and gain such knowledge in their everyday lives. All interviews were conversation-like, allowing the respondents to reflect on and highlight issues and aspects that they find interesting or important within the scope of the study. In total, 25 interviews with approximately 30 persons were made, all of them conducted during spring and summer 2019 and spring and summer 2020.

While individual interviewees discussed certain practices such as apple preservation, sausage making, fishing techniques and traditional building techniques, there were some areas that engaged several interviewees and we will introduce these briefly here.

One area is seed keeping. Many interviewees grow seeds in private gardens, allotments, collectives, outdoor museums and local history societies. Several of them are members of Sesam, a national organization that since the 1980s has been active in seed keeping, to create a larger range of varieties, and to preserve old, traditional, local, or rare varieties of vegetables.

Several interviewees are engaged in urban gardening. The practice of growing food in cities has emerged for various reasons in different times, but has often been formulated as a way to provide food security [7]. However, urban gardening today is less about survival and interviewees describe their interest in growing their own food, often organic, and often highlight the recreational values in gardening work and putting their hands in the soil. As urban cultivation areas often are shared by people that either are neighbours or engage in the same gardening association, the practice of gardening and growing foods also has bearing on social relations and sense of community that forms in these contexts.

Several interviewees engage in various gardening associations and cooperatives. This includes organizations focused on growing flowers and vegetables, small-scale organic cultivation and self-sufficiency, medicinal herb gardens, allotment gardens, and associations with interest in nature, ecology, and cultivation. These associations are local and may have a focal site such as an actual display garden, but they rarely have a garden where members cultivate together. Rather, the associations are platforms where members improve their knowledge and cultivate their interests. Moreover, some interviewees are engaged in gardening cooperatives, where a group of people share both the spaces to cultivate, the work with the cultivations, and the harvests. We have interviewed those who engage in cultivation in a city park, those who keep a gardening space outside the city, as well as those who share a gardening space with their neighbours. In addition to local organisations, several interviewees are members of or have participated in activities organised by the national organisation FOBO (Förbundet organisk-biologisk odling), that since the 1970s has 
promoted organic cultivation and specific methods of using compost and organic materials to improve soil quality.

The example of scythe mowing with which we opened this text is also widely represented in the interview material. The practices of scythe mowing and hay-piling are recurrently mentioned in the interviews and can be seen as examples of traditional methods that are made a part of contemporary small-scale agriculture. Both the practice of using a scythe and piling hay are described among our interviewees as something that has gone from a common sight in the fields and a widely spread knowledge to an increasingly rarer phenomenon. However, in recent years, the interest to preserve these methods has grown. This interest is reflected in activities and courses carried out by various associations focused on for example local history and cultural heritage-but also activities and courses arranged by the regional government authority the County Administrative Board (länsstyrelserna).

Several of the interviewees are engaged in beekeeping. A few of them are members in the national association Swedish Beekeepers Association (Sveriges Biodlares Riksförbund) and keep beehives in their gardens. Beekeeping was traditionally a common element in the self-sufficient households but declined when agriculture became industrialized. However, there has been a renewed interest in beekeeping and the practice is now on the rise again.

Another area investigated is local history societies. In times where small-scale and self-sufficient agriculture largely has been replaced by industrial agriculture with fewer and larger farms, local history societies have an important role in keeping objects and tools traditionally used to farm land and grow food. They often keep museums with traditional everyday objects and documentation from the past, and their work is often focused on collecting, storing and showcasing traditional objects. Thereby they both preserve stories and memories of traditional methods and customs of rural life in the past, as well as knowledge about everyday life in older times.

Lastly, some of our interviewees are small-scale commercial entrepreneurs who are incorporating traditional, although not necessarily local, practices in their enterprises.

Following this introduction, the paper will treat the concept of revitalization in some detail, providing an overview of how the concept has been used and suggesting how it can bring insights to studies of sustainability. Then, it will use the empirical material to illustrate these aspects.

\section{Revitalizing Revitalization}

In our discussion of how the concept of revitalization can have a bearing on sustainability and traditional agrarian practices, we will start by going back to Wallace's 1956 definition we referred to earlier, where he saw revitalization as a "deliberate, organized, conscious effort by members of a society to construct a more satisfying culture" ([5], p. 256). Wallace's original work on revitalization was within the anthropology of religion and sprung out of his research on the Seneca prophet Handsome Lake (1735-1815). Since the concept of revitalization was coined by Wallace in this context, it has often been applied to the study of religion, not least for historical religious movements. In Wallace's understanding, 'revitalization movement' was a term that could cover phenomena such as nativistic movements, cargo cults, millenarian movements or messianistic movement. Wallace stresses that revitalization movements are common and recurring phenomena throughout human history, which have been successful to various degrees. Christianity would be a prime example of a revitalization movement with profound historical importance (Wallace 1956). Wallace primarily dealt with religious movements and although he provided that the degree of religiosity might vary, he also states that "No revitalization movement can, by definition, be truly nonsecular" ([5], p. 277). However, his definition is sufficiently broad to allow for a wider range of phenomena than he originally had in mind, and Wallace has himself noted that the concept has been routinized and applied to contexts quite far removed from its origin [8]. Our intention is not to be true to Wallace's original meaning of the concept, rather, we treat it as a conceptual tool which can give insights into phenomena quite different from those Wallace originally had in mind. As Dovey has noted "different 
conceptual tools may be useful for different intellectual tasks, even those for which they were not intended" ([9], p. 13).

Wallace's work has informed studies of how a turn to tradition has inspired social change [10], investigations of historic or contemporary religious movements [11,12], and many of the contributions to [13], tourism and cultural identity [14,15], customs or festivals or games [16]. Research on revitalisation has often been used in relation to minority groups, often suffering from a history of oppression, who reclaim their heritage [13], for instance in the form of learning a threatened ancestral language [17-19]. The works cited here do not constitute a comprehensive list of works dealing with the concept of revitalization, and an even greater body of work of course deals with related phenomena but using other analytical concepts. The use of the revitalisation concept often reflects a polarization between small-scale and large-scale community, or between the local and the national or global, as it protects local habits and customs against national or global cultural homogenization. Revitalization can also aim at safeguarding local values threatened by globalization processes.

While we find Wallace's general definition of revitalization movements and many of his insights into these movements inspirational, there are also a number of problems with his analysis. In his treatment of the revitalization concept, Martin [20] is rhetorically questioning the relevance of a "middle-aged theory", and adding almost another two decades since Martin's text, the theory may be considered to have reached retirement age. There are indeed many elements of Wallace's take on revitalization that may seem outdated or at least typical of mid-20th century thinking in anthropology; it is systemic, organismic, defines stages and can be considered 'bound'. As Harkin [21] also demonstrates, the concept is closely tied to European thought, although it has been applied in relation to phenomena worldwide. Despite this, Harkin suggests there are several good reasons for hanging on to the revitalization concept, in some modified form, as it has proved very useful in understanding cultural movements. Not least since the theory is not making assumptions of boundaries, but it acknowledges transcultural exchanges as a premise ([21], p. xviii). It also has the virtue of considering material reality as well as ideology, the individual as well as the collective and the larger cultural context. It is also comparative and allows for connections across time and space ([21], p. xix).

While is the concept is turned towards explanation rather than interpretation, Harkin suggests it may be better to view revitalization "as closer to a literary genre, in which common elements combine to constitute a basic structure, which is then subject to transformations.... Such a model allows for, indeed assumes, transformation of basic elements" ([21], p. 144). This view is supported by the widespread use of the concept and suggests flexibility and adaptability.

For our purposes, the concept offers several insights. As well as the overarching notion of "deliberate and conscious efforts" and the transformation that these efforts are directed towards, which concerns larger issues of human relationship to the environment, revitalization directs our attention to issues of time and the relationship between past and present, to cultural change and perceptions of stress, and to circulation of knowledge and practices.

\subsection{Past and Present}

There is an inherent temporal dimension to both the concept of revitalization and the concept of sustainability. The latter can be claimed to be "future-oriented" [4], while the former embody a relationship to the past. Both concepts also highlight different, even contradictory, perceptions of time. This refers not least to cyclical and linear time, but also to how what might be termed mundane and mythical time relate to one another ([21], p. xxiii). The transformation that revitalization movements strive for has temporal dimensions. In our context, this temporal dimension might be interpreted as nostalgia. A longing for the good old days. However, there is more to it than this. Di Giovine $[15,16]$ elaborates on the conceptions of linear and cyclical time, where he suggests that the revitalization concept embodies a cyclical 
conception of time-linked to the growing cycles of nature: "Revitalization movements also operate with an understanding of society that structurally resembles a seasonal, agrarian life cycle: one's culture, such as one's food, can be germinated, flourish, grow sick, and become reborn" [15]. Similarly, Vogt and Weber suggest that "the planning and anticipating of the economy in the ecological metabolic cycle and its rhythms of time" goes to the core of the concept of sustainability ([4], p. 2).

As we are dealing with pre-industrial agrarian practices, there is an inherent relationship with the past. The investigated practices can be understood as traditional and creative processes on a continuum between continuity and change. Following Handler and Linnekin [22], we understand tradition as neither genuine nor spurious, but always both. Tradition is made in the present and must always be adapted and kept up to date for it to be passed on. Such adaptation is characterized by negotiation, and by choices. In such an understanding, tradition is thus a dynamic concept, always made in the present, never fixed but constantly evolving.

There is thus a processual dimension of tradition, and tradition is further a concept that only makes sense in relation to modernity, but traditions are not necessarily old [23,24] and the dichotomy between tradition and modernity is false in the sense that these are not fixed or mutually exclusive states ([22], p. 273). This is well in line with Glassie's definition of tradition as "the creation of the future out of the past" [25].

In the way we use the terms, there is a certain overlap between revitalization and tradition but there are also key differences. To some degree they operate on different levels, as when we speak of a "revitalization of tradition", although such a phrase may in itself suggest tradition as static object and not the dynamic process we have sketched above. Rather, revitalization is one form that the ongoing transformation of tradition might take. That said, tradition is a term that implies continuity, albeit not in a static or unchanged form. Revitalization on the other hand hints at discontinuity or stagnation. The very word revitalization implies that something has been dead or dying, or at least that there is a gap-a discontinuity with the past ([26], p. 261). This discontinuity has led Di Giovine to suggest that:

"... the content of a revitalization movement can be considered a reinvention of tradition - a discontinuous break with the immediate past in favor of earlier values or processes that are considered more authentic, but have been lost or obscured. While the society may believe it is simply returning to an unaudulated state, it really creates a radically new worldview that melds imagined past values with contemporary ones." ([15], p. 78)

We understand revitalization as a process of negotiation and adaptation to the present, where no tradition can be picked up in a static or unchanged form. As Handler and Linnekin had already noted in 1984: "It is by now a truism that cultural revivals change the traditions they attempt to revive" ([22], p. 276). Revitalised practices are both recontextualised and reworked. Revitalization is made in a space between the past, present and future, and this is a space where "change" occupies a central place.

\subsection{Change and Stress}

Revitalization is a culture change theory. Wallace originally framed revitalization movements as a response to culture change, or rather to stress caused by culture change. Di Giovine suggests that revitalization movements are reactions to cultural contact and interactions with some kind of outside society which has brought about transformations, that for some are seen as undesirable. The revitalization movement then can be seen to be "fuelled by the society's desire to restore ideal cultural values" ([15], p. 78).

As the theory has become closely linked to minority cultures, whose experience of culture change often has been paralleled by increased marginalization, the concept has frequently been tied to deprivation and responses to deprivation. As Harkin notes:

"the typical case involves a group declining in political power, wealth, well-being, population, or, usually, a combination of these that develops a movement out 
of a bricolage of its own cultural materials, with the explicit purpose being to eliminate or at least exclude the threatening dominant group." ([21], p. xxix)

Harkin and other contributors to his edited volume wish to go beyond this notion of deprivation. We support this view, and maintain that revitalization is not limited to minority cultures, but revitalization processes can also be found within majority cultures and privileged subcultures. In this paper, our interviewees predominantly represent majority culture and are not marginalized, however, a sense of deprivation or loss seems to be an important aspect in the practices our interviewees engage in. The lifetimes of especially older interviewees have seen great changes, several of them describe childhoods on small self-sufficient farms of a kind that rarely exists anymore. The past decades have been scenes of intense social and cultural change. While these changes have led to a higher standard of living and material well-being, they are also perceived as having had negative effects, not least in terms of human relationship to the environment. Since 1945, the world has been facing a 'great acceleration' [27] of human impact on the environment. This great acceleration consists of complex man-made environmental pressures relating to intensified modernization and industrialization.

While change then may not necessarily have to led to deprivation, there is a clear link between change and stress in the revitalization framework. However, stress is not necessarily associated with negative change, it can also correlate with enlarged opportunities as this opens possibilities for "communities and individuals to desire new visions, to crave change, and to rethink codes" [20]. These changes can be perceived as both liberating and threatening. In both negative and positive change, there is frequently an external catalyst. That cultures are not isolated entities is a key point in revitalization theory, and contact with others spurs both change and responses to change.

\subsection{Revitalization as Bricolage}

In line with a dynamic perception of tradition, it must be acknowledged how revitalization may promote hybridity, mixing and cultural borrowing. While most of the practices we have investigated reflect methods and customs that historically have been common in the specific area, there are also some examples of practices that could be termed traditional from other parts of the world. One of the virtues of the concept of revitalization, from our point of view, is that it can bring together both native, traditional and imported practices and 'content'. As Lepowsky [28] notes, "Wallace makes the key point that revitalization movements embody an ambivalence regarding 'traditional and imported cultural material'" ([28], p. 45). The movements are syncretic. In an earlier quoted passage from Harkin, he uses the term bricolage to describe the revitalization movement. And both the Levi-Straussian ([29], p. 39) meaning of bricolage as the pattern of mythological thought that re-uses available material to create something new, and wider understanding of bricolage as using and improvising with materials at hand is useful for understanding the processes of revitalization in general and many of the practices we have investigated in particular. Bricolage entails the combination of different materials of different origins to achieve the goals at hand. It is both inventiveness and practical problem solving.

\subsection{Knowledge and Learning}

The practices that are being revitalized are tied to knowledge and learning, often they represent embodied or practical knowledge. Whether these are skills, customs or beliefs, they must be learned by someone to flourish. Knowledge must be transferred. Here, studies that apply the revitalization concept loosely can none the less be illuminating. Studies of language revitalization shows how there are radical transformations in how languages are learned. Revitalization is needed precisely because few people learn the language at home, as native speakers, as their first language. Instead, other ways are introduced. In her study of Sakha language revitalization in Russia, Chevalier [18] for instance emphasizes the formal education system. Suleymanova [17] shows how social media plays a role in Tatar language revitalization in Russia. In our material, many of 
the surveyed respondent are actively engaged in learning activities, where they provide the knowledge of specific practices. They also exhibit a diversity in how they themselves learned the practice, where courses, books, online forums, and social media complement 'learning by doing' and learning directly from others.

In Martin's [20] thorough engagement with the revitalization concept, relating to the 19th century Cherokee woman Catherine Brown, he points out that she was part of efforts of creating more satisfying culture "by pursuing formal education, building schools, and teaching other Cherokees to read and write." ([20], p. 82). In that sense, introducing new forms of knowledge, education and learning can also in some cases be seen as revitalization.

\section{Seeds of Change}

Tradition, according to Handler and Linnekin [22], can be seen as an "ongoing interpretation of the past". Many of our interviewees are engaged in practices that constitutes this continued engagement with the past, albeit in quite different ways. Several of the interviewees are active seed keepers, and growing seeds can also be seen as revitalization of traditional knowledge, where heirloom varieties are preserved as stories, memories and carriers of historic authenticity. Seeds are a form of living heritage, where constant work is required to propagate and keep them alive. Except in ideal conditions, seeds cannot just be kept for long periods of time, they have to be constantly grown season after season and as each plant is not genetically identical there are also subtle changes to the varieties as they are being preserved. Of course, seeds can also be grown for the purpose of preserving the gene-pool for modern breeding, or simply as a way to get seeds. Although a few of our interviewees suggest seed keeping is also economical, they more prominently emphasise preservation of varieties and, in some cases, an ideological resistance to big seed companies. One interviewee describes his motivation to grow his own seeds as a response to how big seed companies shape their supplies and range of varieties in accordance with their profit motives, rather than in accordance with values linked to small-scale cultivation or varieties that is cultivated for the sake of preservation (this is very much in line with what Catherine Phillips found among Canadian seed savers, see [30]). Several interviewees also express a sense of satisfaction from being self-sufficient, even if in a limited sense.

For some interviewees, the act of growing seeds and preserve varieties is a way to cherish memories of the past. The keeping of seeds can be tied to an interest in the local, a way to preserve local varieties or tastes from their childhood. Some express sentimental attachment to specific varieties. One interviewee has kept seeds, bulbs, and plants from old raspberry bushes from her parental home-varieties she considers as heirlooms from her parents. Another interviewee, who works as a gardener in a historical outdoor museum where she recreates authentic historical gardens, says that she grows seeds because it feels good to preserve varieties that used to be common in the past, such as soapwort. Soapwort is no longer cultivated and used as soap or detergent in households, but by the act of cultivating such varieties the memories about their usefulness for past generations is preserved. Likewise, herbs and medicinal plants are rarely cultivated for medical purposes today - but by cultivating them, some knowledge about their qualities and uses is also preserved. Another interviewee mentions the bean variety Mor Kristins böna (Mother Kristin's bean), an heirloom variety grown by a woman in south-eastern Sweden in the early 1900s. Mother Kristin gave her bean as a wedding gift to her neighbours, and thereby the variety was preserved-but also the memory of an everyday life of a woman who lived over 100 years ago. Along with the seeds, stories and memories are also kept [30,31], and the seed in itself can be seen as a carrier of historic authenticity [32].

Seed keeping is also described as related to the fact that many traditional varieties are not marketed by seed companies-they can only be kept by growing seeds (and to some extent in gene banks). For example, one interviewee, a member of Sesam who grows her own seeds, told us about her favourite bean, the rare variety Bertina, whose seeds must be grown as they are not available for purchase. One year, she cultivated another bean variety next to Bertina, but there was a very poor bean yield that year and Bertina did 
not look the way it should. Later she found out that bean cross-fertilizes and therefore should not be grown together. Luckily, she had given away Bertina seeds to a friend who could share them, and so she could keep cultivate and preserve this rare variety. This example illustrates how a rare variety's survival depends on those who cultivate it having the specific knowledge and skills required to successfully grow this specific variety, but also the importance of transferring such knowledge to others who grows the variety.

The interviewees involved in the seed-keeping organisation Sesam work individually with a common purpose-to keep the craft of seed growing alive and to preserve rare and traditional plant varieties. Through Sesam, a variety of vegetable and agricultural plants are utilized and preserved by the members in private gardens or small farms, aiming to halt the loss of agrobiodiversity. The association has a focus on Swedish landraces of cultural plants, but commercial varieties as well as plants collected from botanical institutions and gene banks in other parts of the world are also grown and distributed. The work is entirely based on the members' efforts of collecting, growing, reproducing and distributing the most interesting and valuable varieties. The seeds can be used by other members for free. In the interviews with Sesam members, a recurrent theme is that growing seeds requires a lot of knowledge, for example to grow rare seeds successfully or to avoid cross-pollination of similar varieties of heirloom seeds. Sesam acts as a keeper of knowledge providing for example books and courses on seed growing. Importantly, they treat seed growing as a craft, and the association is modelled on the old guild system: in each guild a master craftsman is responsible for a certain type of plant-peas, beans, tomatoes, beets, kale, corn, to mention a few-and is aided by journeymen who grow seeds of the specific varieties. This is both an organization of work, a means of quality control, and a revitalization of an older form of knowledge transmission. Sesam has seen a large influx of new members, it has tripled in size over the past decade and a lot of younger members has joined recently. This growth highlights the revitalization dimension of the work but also poses organizational challenges and changes the patterns of communication and knowledge transmission. While Sesam does not have local branches, one of our participants mentions that members who live in the same area informally arrange gatherings where they learn from and are inspired by one another.

\section{Preserving the Past}

Museums and local history societies that were part of our investigation often has a focus on preservation. They want to preserve a memory of things past, and to document how things used to be done. Preservation is another process of recontextualization or reinterpretation of tradition, as a traditional tool on a museum or a folklore display is something quite different than the same tool in use or the original event the display seeks to recreate. In this way, these clearly emanate from the present, from its conceptual needs and interpretation of the past ([22], p. 280). As preservation is a different process than revitalization, museums and local history societies can be seen as in some ways contrasting to other interviewees. Preserving objects or practices from the past is not necessarily the same as suggesting the practices should still be used, they can be seen as something that belongs to the past.

One of the surveyed local history societies mentioned that they have recordings from the 1970s in their collections in which the older generations describe practices from everyday life in the past. However, these recordings are very hard to interpret for contemporary people: those speaking are describing practices in such a self-evident way, that those who are not themselves versed in this practice understand very little. Similarly, while visiting a local history society to conduct interviews for the study, a member showed us an old agricultural hand tool in wood, similar to a small wheelbarrow. He said: "We do not know what it is, but we think it may have been used to prepare the soil for seeds and to spread seeds in rows". A wooden agricultural tool or recordings of elderly describing traditional practices remains over time, but the knowledge of how to use the tool or to understand the recordings has gone lost. Harkin [33] suggests that revitalization is not only about reviving 
or bringing to life, it can also mark something lost. What may have begun as attempts to revive, can become ritual markers of loss ([33], p. 145). In this way, revitalization is perhaps not only a contrast to but also akin to preservation. To preserve objects of the past is a way of marking and commemorating the loss. That there indeed is a loss, can be illustrated by these objects and stories that local history societies keep but cannot fully make sense of.

The practice to use a scythe and to build hay-piles is recurrently mentioned in the interviews as examples of traditional methods that contemporary small-scale agriculture make use of. As mentioned earlier, these are methods that have attracted a lot of interest in Sweden in recent years, both for their potential to promote biodiversity and for their cultural heritage values [34]. One interviewee who as a child learned many traditional practices and customs, describe his childhood memories of watching the elderly in the village perform these activities: "One could see that things had been done this way for a really long time [... ]. And today, you almost never see a hay-pile in the fields - you only see white silage bales". He continues: "if we have a couple of generations who doesn't want to preserve this cultural heritage and these knowledges... then the knowledges and skills easily die out". To preserve the practice, he continued using it: "we piled hay even after the method was dated, just to show our daughters how to do it".

A common denominator between almost all of the interviews is how there is a consciousness in relation to many of the practices the interviewees engage in. While the interview itself of course invited the participants to reflect upon their practice, it is striking how rarely they referred to 'pure habit'. People have taken deliberate steps, such as courses, to learn specific techniques and some interviewees who learned certain practices a long time ago have clearly articulated reasons for continuing with these.

Preserving the past is closely intertwined with knowledge transfer. Knowledge about various agrarian practices, techniques, methods or customs needs to be used and transferred, and as it travels it will also change. If fewer are using such methods, the movement will slow down and perhaps stop, and the knowledges risks being lost.

We earlier suggested that revitalization depends on new patterns of learning and knowledge circulation. In a report on traditional knowledge and modern agriculture in Sweden, Peter Einarsson [35] suggests that traditional knowledge still is important in Swedish agriculture. He defines traditional knowledge as traderad kunskap, i.e., knowledge that is handed over directly (orally) from one person to another. Einarsson thus defines traditional knowledge not in terms of its content but in terms of how the knowledge circulates. He also notes that it is common among peasants today to have been raised on a farm, generally the one they are working. Among his interviewees he had both the category who were born and raised peasants, and others who have moved to the countryside and taken up farming as adults. One of them likens the learning of agriculture with learning a new language, i.e., while this is possible to do as an adult, you will always have a bit of an accent [35].

In keeping with the view on tradition earlier discussed, Einarsson also demonstrates how traditional agriculture has been far from static but gone through paradigmatic changes over the past centuries. In discussing new forms of knowledge circulation Einarsson suggest that the internet might be more similar to older form of oral and face-to-face communication, compared to a few decades ago when written communication to a greater extent was dependent on printing. Transferring traditional (orally transmitted) knowledge to print required not only writing it down but a degree of formalisation and institutionalisation. While knowledge obtained on the internet is not localized and embedded in practice, the internet enables if not face-to-face so peer-to-peer two-way communication ([35], p. 35).

However, our interviewees demonstrate a wide variety in how they have learned traditional practices. Several did so in their childhood, predominantly the older but also some of the younger research participants. Some have formal education in the area. Shorter courses are frequently mentioned, and organizations serve as arenas for learning. Books, journals and, of course, the internet are also frequently mentioned. Several of the interviewees are also active as educators. The interviewees involved in local history societies 
recurrently describe it as their role to inform the public, and some of the associations arrange various forms of gatherings with an "educational purpose" where they invite the public to participate, for example in slåttergillen (haymaking feasts where participants mow grass with a scythe, build hay-piles, and celebrate after executed work), or to build traditional roundpole fences, a wooden fence traditionally used to fence off animals. The activities are often carried out in collaboration with schools, the County Administration Board, or with other associations, primarily those involved with agricultural practices. The activities contribute to preserving traditional practices by showcasing and enacting them, but they also contribute to keep cultural-historical values in the landscape.

While the past is frequently held forward as a model and traditional practices often are referred to as cultural heritage, several interviewees also warn, or are being warned, against nostalgia. One interviewee, himself a farmer with an interest in past practices who has also been active in farmers organisations, suggested that there are good reasons that many past practices have disappeared. These reasons are not only economic, but also has to do with the quality of the produce. Traditional methods of hay-stacking, for instance, only worked well in the right weather conditions. In bad summers these methods could result in poor quality hay, and even hay that had carcinogens in it. Further, many point out that life as a small-scale, self-sufficient farmer is hard. While older interviewees may be nostalgic about their childhood, they do not wish to bring this way of life back. Younger interviewees who see self-sufficiency as an ideal are being cautioned by older relatives, one cites his father who have told him that "The life you want, it is a punishment".

\section{Working Together}

While engaging in pre-industrial practices may be an individual choice, 'community' is a recurrent theme in the interviews. Some have sought the company of the like-minded by joining an organisation, or have found them on on-line forums. 'Community' may also be perceived as a quality of the past that we have lost, and should strive to revive. This is particularly emphasised by the elderly interviewees who have witnessed great changes to their way of life. One of them grew up on a farm in the 1940s and later took over the neighbouring farm. He says that there were much more social elements to the work on the farm during his childhood in comparison to today. All generations-children, adults, even elderly grandparents-would come together and help with for example hay making. This, he notes, "has gone lost over time". He also describes that the neighbouring farms used to share agricultural implements that they together moved around from farm to farm and helped each other out with some of the heavy chores. "It was by being involved in the work on the farm and discussing different things with neighbours that I learned and gained knowledge", he says.

The longing for community is also a recurrent theme among some of the younger interviewees. The initiators of an urban garden cooperative claims they were inspired by the idea of bygemenskap, a concept describing the local community traditionally shared by people in a village, who helped each other with everyday work and worked jointly on larger, labour-intensive tasks such as forestry, sowing, and harvesting. "We like the idea that people come together and work together", one of them says, "we want to gather people, bring them together, to create positive, good things". The idea to start an urban garden cooperative in the first place was very much linked to their frustration over "bad things in society". They wanted to actively do something that "contributes to goodness". According to them, those involved in the cooperative enjoys to cultivate, but the major motivation seems to be more about wanting to contribute to and support environmentally and socially sustainable activities and initiatives: "the motivation of those who come here to the cooperative are rather ideological, than sprung from a purely cultivating interest". In this cooperative, community, bonding, socializing and sharing is equally important as cultivating land and contributing to small-scale food production. Several of the interviewees describe cooperative gardening as oriented towards social values, where 
activities are based on a sense of contributing to "good things" in society. It is also described as an activity that often engages younger generations interested in ecological sustainability.

Self-sufficiency is another recurrent theme in the interviews, with several older interviewees considering themselves as having grown up in an era of self-sufficiency (now long lost) and several of the younger being interested in living self-sufficient lives, although none of them entirely does so. In her study of Canadian seed savers, Phillips found that self-reliance was an important motive for many of those engaged in seed saving. Selfreliance was seen as a combination of thrift and independence, which also enables control over the production process. Importantly, Phillips point out that "For seed savers the 'self' in self-reliance, as suggested earlier, is not an isolated individual but one immersed in collective processes of provisioning and practice" ([30], p. 203). Self-sufficiency and community can thus be seen to belong together. One of our interviewees, who is very experienced in farming and cultivating, tried to live completely self-sufficient for a time, but "got almost entirely isolated" because of the hard work she had to run all by herself. She says that "for it to work, it requires family or other relationships with people who are as driven, interested and engaged in it as one self", suggesting that self-sufficiency and community goes hand in hand.

The consciousness in learning and revitalizing some of the traditional practices that once were part of many people's everyday life can also be seen reflected in the fact that these practices require time and resources. As one interviewee suggest, being able to grow your own food is today by many considered a privilege-while in the past, it was a necessity for most people. When practices have fallen out of use or out of habit, taking them up is a much more deliberate activity.

Several of the participants in the study were approached as representatives of organisations, but also many of those who were approached as individuals are members of various organisations. Many interviewees describe how membership in an association means that they can participate in inspirational courses, field trips and other activities offered by the association. However, a membership in an association also means that one has a platform to meet with other practitioners who share their interest in cultivation-people to trade seeds and plants with, as well as exchange knowledge, inspiration, and to discuss things with. The practices we have surveyed are to a large extent organized, or at least semi-organized. During the course of the interviews, we discovered ties and connections between different participants in the study that we were unaware of. As a movement, it is rather loose and heterogenous. There is no strong, unifying charismatic leader. While many are critical of how society has developed, there is not much standing on the barricades. Several interviewees voiced concern over global environmental problems, but their action is turned towards the local. The attention is turned inward to everyday acts. While these acts may be individual, they are not isolated.

\section{Biodiversity and the Local}

Many of our interviewees emphasise environmental sustainability as a key value. They rarely referred to "hard facts" or research to support their claims (but neither were they asked by us to do so). They turn to traditional knowledge and practices to address contemporary problems, seeing that these practices can be enacted in new ways for a more sustainable usage of environmental resources-which often is about promoting local and small-scale agriculture. This promotion of the local is in many cases connected to a critique of social changes that has led to a push towards large scale agriculture, associated monoculture and long-distance transportation. The Swedish agricultural sector is heavily reliant on fossil fuels, both from transports and agricultural machines [36], and a reduced dependence on fossil fuel was together with increased (agro)biodiversity the benefits most frequently mentioned in the interviews. Production methods that promote biological diversity is part of Sustainable Development Goal 12, and organic farming is found to beneficial in this respect [37]. However, it can be debated whether small-scale agriculture and self-sufficiency are feasible as models for sustainability in modern, urbanized and industrialized world ([4], p. 3) [38]. That said, 
the cultural value attributed to local production, small-scale agriculture and self-sufficiency should not be underestimated.

One of the organisations we have investigated, a centre that gathers associations focused on nature, ecology and cultivation, keeps a local gene bank where they cultivate local rare and endangered plants. The organisation keeps the seeds from the plants, but they also share seeds to NordGen, the Nordic countries' gene bank. The interviewees associated to the organisation and the gene bank describe their work to preserve rare varieties as a reaction to monoculture. One of them says that the pesticides that are used in agriculture today kills rare varieties, and the gene bank is "an active attempt to preserve these varieties". The gardener at the centre says that he sometimes uses some of the seeds from the gene bank and spreads them "here and there ... so the seeds can disperse and the variety can live on in the wild".

Diversity is typically associated with small-scale. Many of the interviewees cultivate organically, and several of them express their awareness on growing both flowers and vegetables since the variation favours pollinators and biological diversity. They also highlight scything as part of this awareness on biological diversity. One interviewee who cultivates traditional varieties of vegetables says that he likes them because they are adapted to the local conditions and have been grown and bred into a tradition of small-scale. Among other varieties, he grows field peas (Pisum sativum var. arvense), which is one of the oldest domesticated varieties and historically has been an important staple food for people in the Nordic countries. He says: "They are more fun than regular sugar peas [ ... ]. I think we should use these varieties that have ten thousands of years long history here $[\ldots]$ not least because cultivation is interconnected to many different societal issues that very much concerns how we can take care of the earth".

Biological diversity is also a recurrent topic among the interviewees engaged in beekeeping. As with scything, there are explicit references to biodiversity in the resurgence of beekeeping, both with respect to insects and pollination. Beekeeping is by a few interviewees practiced as part of a partially self-sufficient household. However, many of them also talk about how they see beehives in new contexts-in parks and in rooftops in cities. According to one of the interviewees, who himself has kept bees for over 40 years, "beekeeping has never been so cherished as it is today". He refers to the growing number of people who engages in the practice, beehives in new contexts and places, an increasing demand for locally produced honey, and countless books on the subject. However, he also refers to how the view on beekeepers has changed over time, where they in the 1950s and 60s were perceived as "old, conservative reactionaries" - as opposed to today, where beekeeping is perceived as something "exotic, romantic, and exciting". He also notes, tongue in cheek, that it seems to be the grandchildren, not the children, of beekeepers who take up the practice as the children remember their "horrible childhood summers" when they could not go swimming because their parents had to take care of the honey. This surge in interest suggests that though the practice takes different, new, forms, and perhaps is driven by different motives, the attraction of traditional practices can be seen in other societal contexts marked by change.

While most of our interviewees are representatives of the Swedish majority culture, many of them have witnessed intense social and cultural change in their lifetimes. This corresponds to the 'great acceleration' [27] (see also [6]) of human impact on the environment that has occurred at the same time. Many of our interviewees would agree with McNeil and Engelke that human impacts on the environment "are embedded in societies and their traditions" ([27], p. 213). To these participants, a cultural paradigm shift is needed to reverse the current trajectory. For example, one interviewee says that the very reason why he is attracted by traditional practices and methods to cultivate land is because he does not believe in the industrial agriculture: " ... it's not sustainable over time. Hopefully, we will look back in 100 years and think of it as a historical parenthesis". He adds: "I think we need to return to small-scale and the local ... where people are working to earn their own livelihood." 
This perception of the local can also incorporate a global flow of ideas and practices. For example, one of the persons interviewed runs a small-scale business specialized in food crafts such as kombucha brewing and fermentation of vegetables. She mostly uses fruits and vegetables grown on the farm where she lives and berried picked in the nearby forest for her craft: "as someone who grew up on a farm, one is used to eat and use whatever is in season". She also mentions her grandmother as an inspiration for her work today. The grandmother always preserved and pickled the vegetables grown at the farm. In this case, the craft itself is imported-but the "ideas" have connection to the local and the ingredients are mostly locally produced. Another example is an interviewee who is involved in several companies focused on sustainability and environmental work. One of the companies produces biochar and charcoal that is added to the soil as a fertilizer. It is based on an old technique called terra preta that stems from the indigenous people of Amazonas. The technique is supposed to create better conditions for cultivation and helps the soil to bind carbon-which helps decreasing the content of carbon dioxide in the atmosphere, thus connecting the local to the global.

As our focus in this study is agrarian practices, it is perhaps not surprising that growing cycles are a recurrent reference. Cycles and circularity are often invoked as a metaphor for using resources wisely and consciously, and using what already exists around us, for example by taking care of grass clippings to fertilize the soil, by taking care of rain water, or by composting with specific methods. Crop rotation is another example that naturally creates favourable conditions for cultivation. Many participants also express a wish for a more natural life or being more in touch with the changing of the seasons. Di Giovine $[15,16]$ was cited earlier for suggesting that revitalization movements have a temporality that is cyclical and can be linked to natural cycles, and for practices such as seed keeping that are associated with the full growing cycle of plants this is of course an easy parallel to make.

\section{Conclusions: Into the Future}

The concept of revitalization draws our attention to several aspects of the surveyed practices. It highlights issues of temporality, change and stress, the circulation of knowledge and practices, cultural values and moral imperatives. Not least it foregrounds the prominence of "deliberate and conscious efforts" in respect to using traditional methods, and how this relates to wider aspects of human impacts on the environment. The aim of a revitalization movement, according to Wallace, is to create a more satisfying culture. In our interviews, this satisfying culture is envisaged as a sustainable one, which makes space for local production and consumption, improved social relationships, preserved local landscapes and increased (bio)diversity. In all these aspects, the past and traditional agrarian practices are seen as having something to offer.

In many of the interviews, research participants express dissatisfaction with some of the consequences of modernity. The processes associated with the great acceleration are thought of as having created not only ecological but cultural and social problems and alienation from nature. A more satisfying culture is also about reconfiguring, or restoring, the relationship between humans and nature. The push towards large scale is not only about monoculture and long transportations-it has also had social consequences, and it has changed social relations. The approach to traditional practices taken by many of our interviewees is connected to larger issues of human relationship with our environment, but also with one another. It suggests that there are indeed things that we have lost in this respect, perhaps sacrificed for material gains. Revitalizing practices of the past can thus also be an attempt to revitalize these less-tangible qualities. Revitalization can also be seen as a means of coping with the loss of tradition. Preservation of objects and knowledge, albeit in a museal way, is a way of preserving or perhaps creating a connection to a localized past, and potentially also to some of the qualities that we may be perceived to have lost.

For some, the engagement with traditional practices is more of a hobby, for others it is a life-style choice. Several express an ambition to promote systemic change through 
acting locally. In other cases, the ambition is rather to 'tweak' the dominant system by creating pockets of (agro)biodiversity, that are hoped to contribute to resilience, or heritage landscapes. As a movement, it is rather loose and heterogenous, but there are several links between many of the research participants. The concept of revitalization embodies drives for cultural transformation, and while this is expressed in many of the interviews, it remains an open question to what extent this constitutes a movement with potential to contribute to such a transformation. While several organisations included in this investigation have seen a huge influx of new members in recent years, our material is not sufficient to gauge the transformative potential of this movement.

In criticising the processes associated with the great acceleration there is also an implicit criticism of ideas of progress and development that are frequently associated with linear time. There is a temporal dimension to revitalization, where a more cyclical approach to time is frequently taken, but cycles also appear as metaphors for sustainability. The past is seen as important to the present, and as embodying qualities that may help us create sustainable futures. Where traditional practices and past ways of life are held forward as models for a more satisfying and sustainable way of life, this is a quite clear echo of Glassie's earlier quoted definition of tradition as the creation of the future out of the past.

Author Contributions: Conceptualization, J.D.; methodology, J.D. and E.S.; analysis, J.D. and E.S.; investigation, E.S.; writing-original draft preparation, J.D. and E.S.; writing-review and editing, J.D.; supervision, J.D.; project administration, J.D.; funding acquisition, J.D. All authors have read and agreed to the published version of the manuscript.

Funding: This research was funded by Formas, grant number 2018-02326_3.

Institutional Review Board Statement: Ethical review and approval were waived for this study since no interview questions of a personal or sensitive nature were asked. The research is therefore not applicable for review by the Swedish Ethics Review Authority, according to the Ethical Review Act (2003:460) and the General Data Protection Regulation (EU 2016/679).

Informed Consent Statement: Informed consent was obtained from all subjects involved in the study.

Data Availability Statement: The data presented in this study are available on request from the corresponding author. The data are not publicly available in order to protect the privacy of research participants.

Acknowledgments: We would like to thank the interviewees who contributed generously with their time and knowledge to the study. Bodil Axelsson, Martin Fredriksson, Jenny Gleisner, Corinna Kruse, Åsa Nilsson Dahlström, Karin Skill and Håkan Tunón have provided valuable input and comments on various stages during the work with the manuscript.

Conflicts of Interest: The authors declare no conflict of interest.

\section{References}

1. Wahrby, E. Med lie på LiU. Available online: https:/ /insidan.liu.se/nyhetsarkiv/1.780214?l=sv (accessed on 18 September 2021).

2. Ignatieva, M.; Eriksson, F.; Eriksson, T.; Kätterer, T.; Tidåker, P.; Wissman, J.; Ahrné, K.; Bengtsson, J.; Hedblom, M. Pros and cons of transdisciplinary research: A case study of Swedish lawns and their sustainable alternatives. Urban For. Urban Green. 2020, 56, 126799. [CrossRef]

3. Wahrby, E. Blomsteräng Bidrar till Biologisk Mångfald. Available online: https://liu.se/nyhet/blomsterang-bidrar-till-biologiskmangfald (accessed on 18 September 2021).

4. Vogt, M.; Weber, C. Current challenges to the concept of sustainability. Glob. Sustain. 2019, 2, 1-6. [CrossRef]

5. Wallace, A.F.C. Revitalization Movements. Am. Anthropol. 1956, 58, 264-281. [CrossRef]

6. IPBES. Summary for Policymakers of the Global Assessment Report on Biodiversity and Ecosystem Services of the Intergovernmental Science-Policy Platform on Biodiversity and Ecosystem Services; IPBES Secretariat: Bonn, Germany, 2019.

7. Hallgren, K. En Kåhltäppa eij at Räkna: Köksväxtodlingen i 1700-Talets Jordbrukssystem; Sveriges Lantbruksuniversitet: Uppsala, Sweden, 2016.

8. Wallace, A.F.C. Foreword. In Reassessing Revitalisation Movements: Perspectives from North America and Pacific Islands; Harkin, M.E., Ed.; University of Nebraska Press: Lincoln, NE, USA, 2004.

9. Dovey, K. Becoming Places: Urbanism/Architecture/Identity/Power; Routledge: London, UK, 2009. 
10. Liebmann, M. The Innovative Materiality of Revitalization Movements: Lessons from the Pueblo Revolt of 1680. Am. Anthropol. 2008, 110, 360-372. [CrossRef]

11. Marinich, V.G. Revitalization Movements in Kievan Russia. J. Sci. Study Relig. 1976, 15, 61-68. [CrossRef]

12. Norman, S.M. Defining Identity during Revitalization: Taki Onqoy in the Chicha-Soras Valley (Ayacucho, Peru). Int. J. Hist. Archaeol. 2019, 23, 947-979. [CrossRef]

13. Harkin, M.E. (Ed.) Reassing Revitalization Movements: Perspectives from North America and the Pacific Islands; 2004. Available online: https:/ / muse.jhu.edu/book/11674 (accessed on 10 October 2021).

14. Ukaegbu, M.O.; Carr, N.; Tucker, H. Tourism and cultural revitalisation: Local perspectives. Tour. Recreat. Res. 2017, 43, 209-219. [CrossRef]

15. Di Giovine, M.A. The Everyday as Extraordinary: Revitalization, Religion, and the Elevation of Cucina Casareccia to Heritage Cuisine in Pietrelcina, Italy. In Edible Identities: Food as Cultural Heritage; Brulotte, R.L., Di Giovine, M.A., Eds.; Routledge: London, UK, 2018; pp. 77-92.

16. Di Giovine, M.A. Revitalization and counter-revitalization: Tourism, heritage, and theLantern Festivalas catalysts for regeneration in Hội An, Việt Nam. J. Policy Res. Tour. Leis. Events 2009, 1, 208-230. [CrossRef]

17. Suleymanova, D. Creative cultural production and ethnocultural revitalization among minority groups in Russia. Cult. Stud. 2018, 32, 825-851. [CrossRef]

18. Chevalier, J.F. School-based linguistic and cultural revitalization as a local practice: Sakha language education in the city of Yakutsk, Russian Federation. Natl. Pap. 2018, 45, 613-631. [CrossRef]

19. Hinton, L.; Huss, L.; Roche, G. The Routledge Handbook of Language Revitalization; Routledge: London, UK, 2018.

20. Martin, J.W. Visions of Revitalization in the Eastern Woodlands. In Reassing Revitalization Movements: Perspectives from North America and the Pacific Islands; Harkin, M.E., Ed.; University of Nebraska Press: Lincoln, NE, USA, 2004; pp. 61-87.

21. Harkin, M.E. Introduction: Revitalization as History and Theory. In Reassing Revitalization Movements: Perspectives from North America and the Pacific Islands; Harkin, M.E., Ed.; University of Nebraska Press: Lincoln, NE, USA, 2004.

22. Handler, R.; Linnekin, J. Tradition, Genuine or Spurious. J. Am. Folk. 1984, 97, 273-290. [CrossRef]

23. Eriksen, A. Tradisjon og kulturarv. In Folkloristikens Aktuella Utmaningar. Vänbok til Ulf Palmenfelt; Ronström, O., Drakos, G., Engman, J., Eds.; Gotland University Press: Visby, Sweden, 2013; pp. 79-96.

24. Hobsbawm, E. Introduction: Inventing Traditions. In The Invention of Tradition; Hobsbawm, E., Ranger, T., Eds.; Cambridge University Press: Cambridge, UK, 1983.

25. Glassie, H. Tradition. J. Am. Folk. 1995, 108, 395-412. [CrossRef]

26. McMullen, A. 'Canny about Conflict' Nativism, Revitalization, and the Invention of Tradition in Native Southeastern New England. In Reassing Revitalization Movements: Perspectives from North America and the Pacific Islands; Harkin, M.E., Ed.; University of Nebraska Press: Lincoln, NE, USA, 2004; pp. 261-277.

27. McNeill, J.R.; Engelke, P. The Great Acceleration: An Environmental History of the Anthropocene since 1945; Harvard University Press: Cambridge, MA, USA, 2016.

28. Lepowsky, M. Indian Revolts and Cargo Cults: Ritual Violence and Revitalization in California and New Guinea. In Reassessing Revitalization Movements; Harkin, M.E., Ed.; University of Nebraska Press: Lincoln, NE, USA, 2004.

29. Lévi-Strauss, C. Det vilda tänkandet [La Pensée Sauvage]; Arkiv Förlag: Lund, Sweden, 2014.

30. Phillips, C. Saving More Than Seeds: Practices and Politics of Seed Saving; Routledge: London, UK; New York, NY, USA, 2016.

31. Nygårds, L.; Leino, M. Klint Karins Kålrot och mor Kristinas Böna: Om fröuppropets kulturarv. Alnarp. 2012, Volume SLU. Available online: https:/ /libris.kb.se/bib/14705345 (accessed on 10 October 2021).

32. Jordan, J.A. Landscapes of European Memory: Biodiversity and Collective Remembrance. Hist. Mem. 2010, 22, 5-33. [CrossRef]

33. Harkin, M.E. Revitalization as catharsis. In Reassing Revitalization Movements: Perspectives from North America and the Pacific Islands; Harkin, M.E., Ed.; University of Nebraska Press: Lincoln, NE, USA; London, UK, 2004.

34. Lennartsson, T.; Westin, A. Ängar och Slåtter: Historia, Ekologi, Natur-Och Kulturmiljövård; Riksantikvarieämbetet: Stockholm, Sweden, 2019.

35. Einarsson, P. Traditionell Kunskap i Modernt Lantbruk; Centrum för Biologisk Mångfald: Uppsala, Sweden, 2015.

36. Eriksson, C. Livsmedelsproduktion ur ett Beredskapsperspektiv: Sårbarheter och Lösningar för Ökad Resiliens; Swedish University of Agricultural Sciences: Uppsala, Sweden, 2018.

37. Tuck, S.L.; Winqvist, C.; Mota, F.; Ahnstrom, J.; Turnbull, L.A.; Bengtsson, J. Land-use intensity and the effects of organic farming on biodiversity: A hierarchical meta-analysis. J. Appl. Ecol. 2014, 51, 746-755. [CrossRef] [PubMed]

38. Tunón, H. Lokalt naturbruk, folklig kunskap och förhållandet till mångfalden. In Biologisk Mångfald, Naturnyttor, Ekosystemtjänster. Svenska Perspektiv på Livsviktiga Framtidsfrågor; Tunón, H., Sandell, K., Eds.; CBM:s Skriftserie 121; SLU Centrum för Biologisk mångfald \& Naturvårdsverket: Uppsala, Sweden; Stockholm, Sweden, 2021; pp. 81-91. 